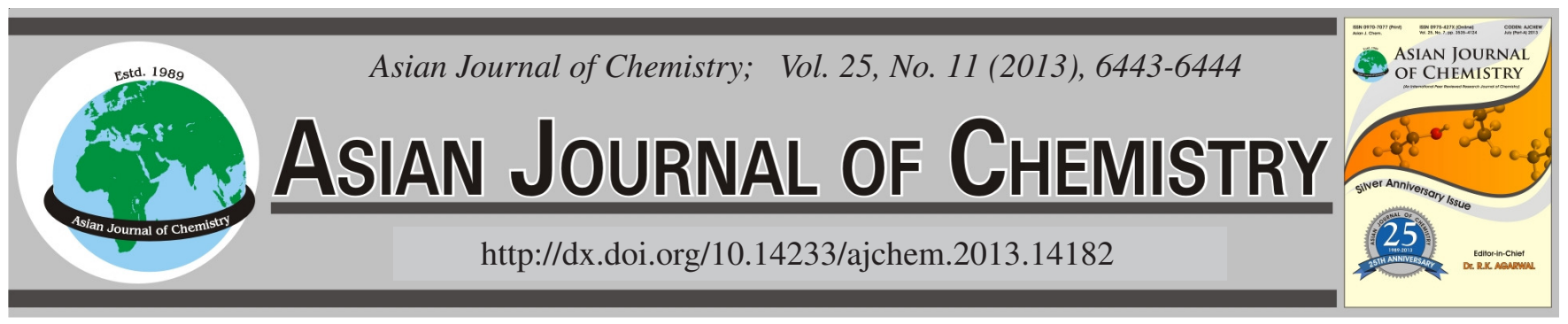

NOTE

\title{
Removal of Contaminant under Different Hydraulic Loading Rate in Constructed Wetland
}

\author{
HaO WANG ${ }^{1, *}$, JiANWEI CHEN $^{1}$ and XUEJIN $\mathrm{Li}^{2}$
}

${ }^{1}$ College of Civil and Architecture Engineering, Hebei United University, Tangshan, P.R. China

${ }^{2}$ Department of Foreign Languages, Tangshan College, Tangshan, P.R. China

Corresponding author: E-mail: wanghao1689@gmail.com

(Received: 7 June 2012;

Accepted: 14 May 2013)

AJC-13488

In Tangshan area of China, the secondary effluent of wastewater treatment plants was used for this study. Horizontal zeolite wetland was carried out treating it. Hydraulic loading rate was the parameters for analyzing the nitrogen and phosphorus removal efficiency of pollutants from the secondary effluent of wastewater treatment plant. Zeolite constructed wetlands showed different behaviours for nitrogen and phosphorus removals. Under the optimum hydraulic loading rate, the primary pollutions were removed to a large extent.

Key Words: Horizontal zeolite wetland, Hydraulic loading rate, Primary pollutions removal rates.

Secondary effluent of wastewater treatment plants is further treated exiguously. In most instances, the effluent is direct discharge to rivers and it will bring about river pollutions marginally. Thus, the secondary effluent of wastewater treatment plants is necessary to be treated to reduce any possible impacts on rivers.

Constructed wetlands $(\mathrm{CWs})$ for wastewater treatment have been extensively applied in many fields, including municipal wastewater ${ }^{1}$, ground surface polluted water ${ }^{2}$, farm dairy wastewater $^{3}$, oilfield drainage ${ }^{4}$ and eutrophic aquaculture wastewater ${ }^{5}$. Constructed wetlands is an aquatic ecosystem mainly composed of plants, microbes and substrate. With the coordination of these components, the constructed wetlands can work smoothly and achieve optimum purification capability $^{5-10}$. Hydraulic loading rate, a key operational condition of constructed wetlands, has a significant effect on chemical pollutant removals. This study focuses on using horizontal subsurface flow constructed wetlands for treating micopolluted water on the variations of chemical pollutant concentration with the hydraulic loading rates.

Experimental system: The experiment took place in a laboratory with a controlled environment in Tangshan of P.R. China. The experimental system consisted of one $1 \mathrm{~m}^{2}$ wetland mesocosms ( $1.6 \mathrm{~m}$ long $\times 0.6 \mathrm{~m}$ large $\times 0.6 \mathrm{~m}$ deep). Gravel, a particle diameter of $15-25 \mathrm{~mm}$, was laid at the bottom of system and the depth was $0.10 \mathrm{~m}$. Zeolites were laid at the middle layer, the particle diameter of them was $6-10 \mathrm{~mm}$ and the depth was $0.20 \mathrm{~m}$. The upper beds were consisted of lytag of a depth of $0.15 \mathrm{~m}$ and the particle diameter was 3-5 mm. The sieving soils were laid at the uppermost layer and the depth was $0.05 \mathrm{~m}$. Phragmites and reed mace were planted in the soils. In the meanwhile, the interplanting ratio of plants was 1:1.

Influent quality: The raw wastewater, secondary effluent of wastewater treatment plants, was collected from wastewater treatment plant in Tangshan. The composition of the influent used in all experiments is shown in Table-1.

\begin{tabular}{lcc}
\multicolumn{3}{c}{ TABLE-1 } \\
\multicolumn{3}{c}{ CHARACTERISTICS OF THE WASTEWATER } \\
\multicolumn{2}{c}{ SAMPLE USED IN THE EXPERIMENTS } \\
\hline \multicolumn{1}{c}{ Parameter } & Unit & Concentration \\
\hline $\mathrm{pH}$ & - & $6.5-8.0$ \\
Ammonia nitrogen $\left(\mathrm{NH}_{3}-\mathrm{N}\right)$ & $\mathrm{mg} \mathrm{L}^{-1}$ & $24.5-32.7$ \\
Total nitrogen (TN) & $\mathrm{mg} \mathrm{L}^{-1}$ & $37.7-45.1$ \\
Total phosphorus (TP) & $\mathrm{mg} \mathrm{L}^{-1}$ & $4.5-5.0$ \\
\hline
\end{tabular}

Removal of $\mathbf{N H}_{3}$-N: As shown in Fig. 1, in the initial pilot phase, the removal effects on $\mathrm{NH}_{3}-\mathrm{N}$ in horizontal zeolite wetland system were obvious and the effluent reached the lowest concentration of $0.28 \mathrm{mg} / \mathrm{L}$, meanwhile, the removal rate reached $97 \%$. Moreover, this study showed certain regularity for removal trends, namely, with the hydraulic load decreased, the removal efficiency gradually increased. By the end of the pilot phase, the decline may be due to temperature, resulting in removal of $\mathrm{NH}_{3}-\mathrm{N}$ conditions gradually deteriorated, so horizontal zeolite wetland of $\mathrm{NH}_{3}-\mathrm{N}$ removal rate decreased slightly. The hydraulic tested at different load conditions of continuous operation, the hydraulic loading of 0.278 $\mathrm{m} / \mathrm{d}$, the wetland system effluent $\mathrm{NH}_{3}-\mathrm{N}$ concentrations in the range of $0.54-3.39 \mathrm{mg} / \mathrm{L}, \mathrm{NH}_{3}-\mathrm{N}$ removal rate of wastewater maintained the range in $66.7-94.6 \%$; on the contrast, when 


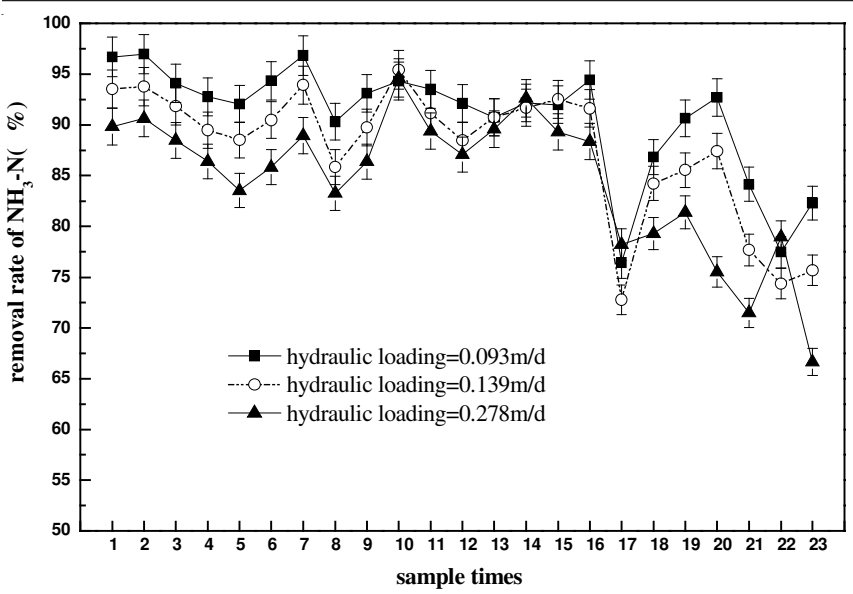

Fig. 1. Removal effect on ammonia nitrogen in horizontal zeolite wetland under various hydraulic loading

the hydraulic loading reduced to $0.093 \mathrm{~m} / \mathrm{d}$, the removal of water rate range increased to 76.4-97\%.

Removal of total nitrogen (TN): As shown in Fig. 2, the TN in horizontal zeolite wetland system was removed efficiently and obviously. In this pilot phase, the horizontal zeolite wetland effluent of TN concentration reached the lowest $1.38 \mathrm{mg} / \mathrm{L}$, while the removal rate reached $93.1 \%$. Moreover, this study showed certain regularity for removal trends, namely, with the hydraulic load decreased, the removal efficiency gradually increased. The removal effect on TN removal increased gradually. The hydraulic tested at different load conditions of continuous operation, the hydraulic loading of $0.278 \mathrm{~m} / \mathrm{d}$, the wetland system effluent of TN concentrations maintained at the range of 3.22-6.58 $\mathrm{mg} / \mathrm{L}$ and $\mathrm{TN}$ removal rate of wastewater maintained at a range of 63.4-82.0\%. In addition, when the hydraulic loading reduced to $0.093 \mathrm{~m} / \mathrm{d}$, the range of wetland wastewater removal rate increased to $74.8-93.1 \%$.

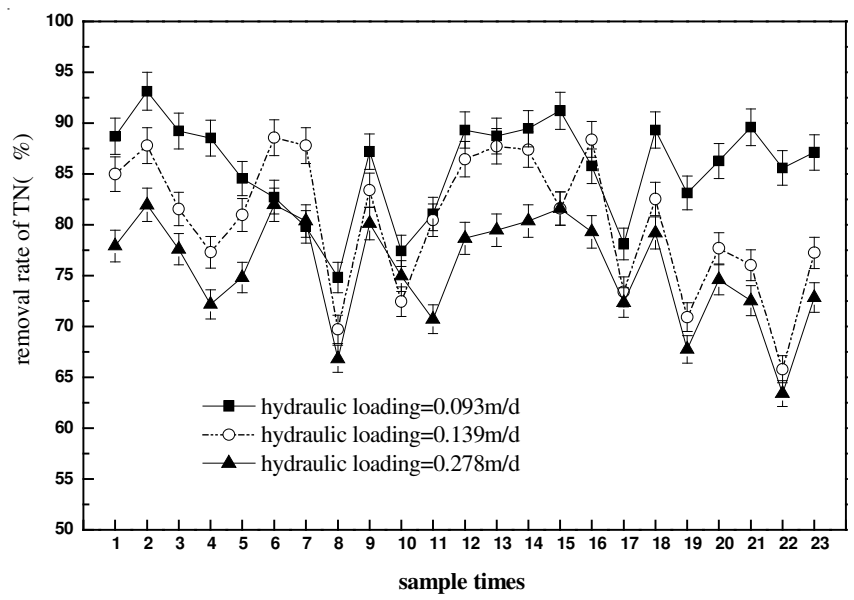

Fig. 2. Removal effect on total nitrogen in horizontal zeolite wetland under various hydraulic loading

Removal of total phosphorus (TP): Fig. 3 showed the hydraulic load on different operating conditions and in certain running time, horizontal zeolite wetland system of TP concentration was low, the lowest concentration could reach $0.10 \mathrm{mg} / \mathrm{L}$ and removal rates acheived to $89.6 \%$. In this pilot phase, with the hydraulic load decreases, the system removal efficiency of TP gradually increased. Under the hydraulic loading of

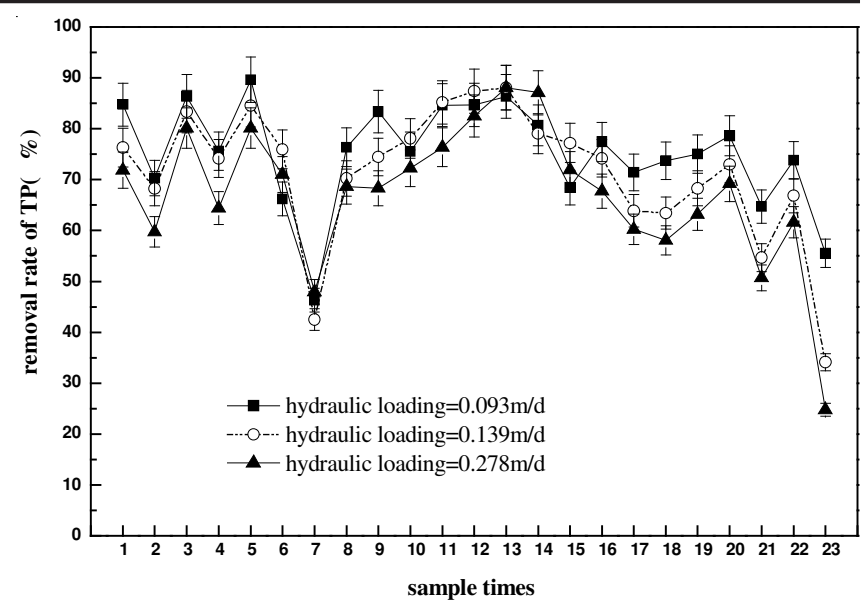

Fig. 3. Removal effect on total phosphorus in horizontal zeolite wetland under various hydraulic loading

$0.278 \mathrm{~m} / \mathrm{d}$, the wetland system effluent of TP concentrations maintained at the range of $0.16-0.65 \mathrm{mg} / \mathrm{L}$ and TP removal rates of effluent could maintained at the range of 24.8-88.1\%. And when the hydraulic loading reduced to $0.093 \mathrm{~m} / \mathrm{d}$, the TP concentration of effluent reduced to the range of 0.10-0.39 $\mathrm{mg} / \mathrm{L}$, the range of wetland water removal rate increased to $55.5-89.6 \%$.

\section{Conclusion}

Horizontal zeolite wetland was carried out to treat secondary effluent of wastewater treatment plants. Hydraulic loading rate was the parameters for analyzing the removal efficiency of pollutants from the secondary effluent of wastewater treatment plant. Zeolite wetlands showed different behaviours for organics, nitrogen and phosphorus removals. Under the optimum hydraulic loading rate of $0.093 \mathrm{~m}^{3} /\left(\mathrm{m}^{2} \mathrm{~d}\right)$, the primary pollutions were removed to a large extent. And the maximum removal rates of $\mathrm{NH}_{3}-\mathrm{N}$, total nitrogen and total phosphorus could reach to $97.0,93.1$ and $89.6 \%$, respectively.

\section{ACKNOWLEDGEMENTS}

The financial support of this research by Water Pollution Control and Treatment of National Science and Technology major project (2008ZX07209-003-07) and Tangshan Foundation for Development of Science and Technology, P.R. China (2011111302007b) gratefully acknowledged.

\section{REFERENCES}

1. Anamika, Asian J. Chem., 20, 4659 (2008).

2. N. Mehrdadi, A. Rahmani, A.A. Azimi and A. Torabian, Asian J. Chem., 21, 5245 (2009).

3. H. Wang, X.W. He, T.Q. Liu and C.H. Zhang, Fresenius Environ. Bull., 20, 2890 (2011).

4. C.C. Tanner, J.P.S Sukias and P.U. Martin, Water Res., 32, 3046 (2007).

5. G.D. Ji, T.H. Sun, Q.X. Zhou, X. Sui, S.J. Chang and P.J. Li, Ecol. Eng., 18, 459 (2002).

6. Y.F. Lin, S.R. Jing, D.Y. Lee and T.W. Wang, Aquaculture, 209, 169 (2002).

7. F. Rivera, A. Warren and C.R. Curds, Water Sci. Technol., 35, 271 (1997).

8. C.J. Richardson and S.S. Qian, Environ. Sci. Technol., 33, 1545 (1999)

9. N. Korboulewsky, R.Y. Wang and V. Baldy, Bioresour. Technol., 105, 9 (2012).

10. C.C. Tanner, J.P.S. Sukias and P.U. Martin, Water Res., 32, 3046 (2007). 